\title{
Pemukiman Kuno Di Daerah Tepi Sungai Batanghari Pada Masa Melayu
}

\section{Bambang Budi Utomo}

Keywords: settlement; river banks; kingdoms of sumatra; history; hinduism; buddhism

\section{How to Cite:}

Utomo, B. B. (1990). Pemukiman Kuno Di Daerah Tepi Sungai Batanghari Pada Masa

Melayu. Berkala Arkeologi, 11(1), 13-26. https:// doi.org/10.30883/jba.v11i1.548

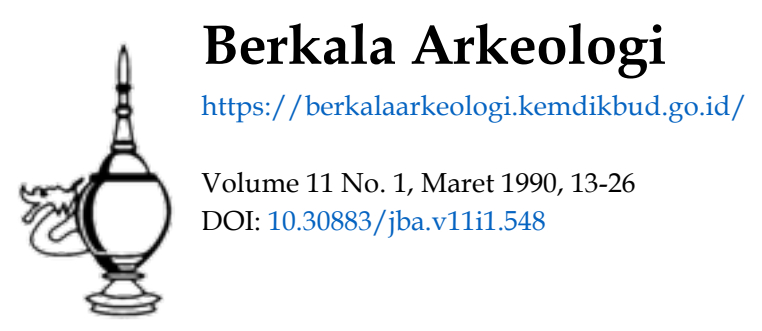




\section{PEMUKIMAN KUNO DI DAERAH TEPI SUNGAI BATANGHARI PADA MASA MELAYU

\author{
oleh: \\ Bambang Budi Utomo
}

\section{Peodarduman}

Pemukiman manusıa dapat tergantung kepada lingkungan tempatnya hidup, meskipun kadang-kadang mereka berusaha mengubah lingkungannya. Di suatu daerat: yang tanahnya subur dan mempunyai kemampuan produksi tanah yang tinggi, biasanya manusia hidup bercocok tanam dengan cara berladang atau bersawah. Menusia yang hidup dilingkungan berawa-rawa dan di lingkungan air seperti di daerah belahan timur pulau Sumatera pun mempunyai strategi penyesuaian yang tersendiri.

Daerah belahan timur pulau Sumatera merupakan tanah aluvial muda yang sebagian besar masih berupa rawa-rawa. Di daerah ini banyak terdapat surigai besar yang mengalir menuju selat Malaka dan selat Karimata. Di antara sungai-sungai besar yang mengalir di daerah tersebut adalah sungai Batanghari dan sungai Musi dengan anak sungainya. Di tepi sungai-sungai ini banyak ditemukan situs arkeologi yang menunjukkan bahwa dj daerah ini telah dimukimi sejak lama. Manusia di daerah tepian sungai bermukim di tanggul-tanggul alam yang daerahnya cukup tinggi dan tidak terkena banjir. Pada saat ini yang kita temukan adalah banyaknya perkampungan di tepian sungai. Perkampungan ini berpola memanjang mengikuti alur sungai. Di bagian belakang dari perkampungan ini masih terdapat rawa yang disebut. "rawa belakang" (back swamp).

Dalam tulisan ini akan diutarakan mengenai permer kiman kuno di tepian sungai. Contoh yang diambil adolah pemukiman di daerah tepi sungai Batanghari wilayah Propinsi Jambi, karena berdasarkan data arkeologi dan data sejarah kedua sumgai ini telah memiliki sejarah yang cukup panjang, yaitu sekurangnya sejak abad ke-7 Masehi. 


\section{Kerajaan Melayu}

Kota maritim yang dapat berkembang tumbuh menjadi kota besar biasanya berlokasi di tepi sungai besar (Kartodirdjo $1977: 2$ ). Demikian pula halnya dengan lokasi Jambi yang sejak dulu terletak di tepi sungai Batanghari. Pelabuhan Jambi diduga dahulu merupakan pelabuhan sungai Batanghari yang lebarnya sekitar 500 meter, sehingga cukup baik untuk pelayaran sungai. Secara geografis Jambi terletak di lintas perdagangan antara India (di bagian barat) dan Cina (di bagian timur), sehingga cukup strategis bagi perkembangan perekonomian.

Di dalam kitab sejarah Dinasti T'ang (abad VIl $X \mathrm{M})$, untuk pertama kalinya disebutkan mengenai datangnya utusan dari negeri Mo-10-yeu pada tahun 644 645. M. Toponim Mo-lo-yeu dapat diidentifikasikan dengan Malayu yang letaknya di pantai timur pulau Sumatera, dan pusatnya di sekitar Jambi. Sementara itu, di dalam berita Arab dari jaman Kekhalifahan Muawiyah (661-681 M) disebut nama negeri Zabag sebagai bandar lada terbesar di Sumatera bagian selatan. Zabag dapat diidentifikasikan dengan toponim Sabag (Muara Zabag) yang letaknya di daerah Tanjung Jabung, di muara sungai Batanghari.

Pada tahun $672 \mathrm{M}$, dalam perjalanannya dari Kanton ke India, I-tsing singgah di Shih-li-fo-shih (=Sriwijaya) selama enam bulan untuk belajar tatabahasa bahasa Sansekerta. Kemudian ia singgah di Mo-1o-yeu selama enam bulan, untuk selanjutnya meneruskan perjalanannya ke India. Pada tahun $692 \mathrm{M}$ ketika untuk kedua kalinya ia datang Mo-1o-yeu dikatakan, bahwa Mo-lo-yeu sudah menjadi negeri Shih-li-fo-shih (Soemadio, 1974: 53).

Uraian I-tsing ini cocok dengan isi prasasti Karangberahi yang ditemukan di daerah Jambi Hulu, di muara Sungai Merangin. Isinya antara lain tentang permintaan kepada dewa yang menjaga Kedatuan Sriwijaya agar 
menghukum setiap orang yang bermaksud jahat dan mendurhaka terhadap kekuasaan Sriwijaya. Dar i keterangan prasasti tersebut diketahui bahwa Sriwijaya berhasil menaklukkan daerah Jambi Hulu (Kerajaan Malayu). (Soemadio 1974 : 56).

Di dalam sebuah berita Cina di sebutkan bahwa pada tahun 853 dan tahun $871 \mathrm{M}$, Chan-pi mengirim misi dagang ke Cináa (Wolters 1974 : 144). Dalam catatan Ling piao lu i yang ditulis dalam tahun $889-904 \mathrm{M}$, disebutkan $P$ i-chan (Chan-pi) menghasilkan sejenis kacang-kacangan yang bentuknya seperti bulan sabit. Orang-orang $\mathrm{Hu}$ engumpulkannya dan diberikan kepada pegawai Cina sebagai curiosities (Wolters 1974 : 144). Menurut. Wolters, toponim Chan-pi atau Pi-chan dapat diidentifikasikan dengan Jambi sekarang.

Berita Cina yang berasal dari masa Dinasti Song (960-1279 M) menyebutkan sebuah kerajaan di Sumatra yang bernama San-fo-t'si. Diuraikan bahwa kerajaan itu terletak di Laut Selatan di antara Chen-la (Kamboja) dan dan She-po (Jawa). Ibukota kerajaan di mana raja bersemayam terletak di Chan-pi. Rakyatnya berdiam di rakitrakit yang ditambatkan pada tepian sungai, sedangkan para pembesar kerajaan berdiam di daratan. Atap rumah hunian di rakit-rakit terbuat dari ilalang (Hirth dan Rockhill 1967 : 62).

Kita mempunyai dua nama untuk menyebut kerajaan di Sumatera yang keduanya mengacu kepada nama Sriwijaya. Kedua nama itu adalah Shih-li-fo-shih dan San-fo-tsi. Nama Shih-li-fo-shih dikenal oleh para pakar sejarah dan arkeologi sebagai nama dari Kerajaan Sriwijaya sebelum abad ke-9 M dengan pusatnya di Palembang. Setelah Sriwijaya memindahkan ibukotanya ke Jambi, penyebutannya berubah menjadi San-fo-tsi. Masalahnya, bagaimana halnya dengan Malayu. Untuk nama kerajaan ini berita Cina telah menyebutkannya dengan nama Mo-10-yeu, seperti yang diberitakan oleh I-Tsing. 


\section{Kepurbakalaan Muara Jambi}

Situs Percandian Muara Jambi mempunyai luas sekitar 12 kilometer persegi. Hingga saat ini, di areal situs terdapat sekurangnya 33 buah sisa bangunan bata. Sebagian dari bangunan-bangunan bata tersebut mengelompok di suatu tempat yang dikelilingi pagar tembok, misalnya Candi Teluk (di seberang selatan sungai Batanghari), Kembarbatu, Gedong, Gumpung, Tinggi, Kota Mahligai dan Kedaton, sebagian lagi merupakan suatu bangunan tersendiri yang letaknya terpisah-pisah, misalnya Candi Astano, Manopo Melayu dan manopo-manopo kecil lainnya.

Di bagian luar kelompok candi yang dibatasi dengan pagar tembok keliling terdapat parit yang juga mengelilingi kelompok percandian itu. Permukaan tanah halaman kelompok percandian ini lebih tinggi dari permukaan tanah di luar parit keliling (sekitar 1 meter). Di beberapa tempat permukaan tanah halaman diperkeras atau dilapisi dengan lantai bata, misalnya pada Candi Tinggi, Candi Kembarbatu dan Candi Teluk.

Situs Percandian Muara Jambi merupakan situs keagamaan yang bersifat Budhist. Dalam agama Hindu/Budha dasar pemikiran manusia dalam membangun suatu -ibukota kerajaan dan tempat-tempat yang dianggap sakral ialah kepercayaan tentang kesejajaran antara makrokosmos ( = jagad raya) dan mikrokosmos (= dunia manusia). Menurut kepercayaan ini manusia selalu berada di bawah pengaruh tenaga-tenaga gaib yang bersumber pada penjuru mata angin, binatang-binatang, dan planitplanit (Geldern 1980:2). Tenaga-tenaga ini mungkin dapat menghasilkan kemakmuran atau mendatangkan kehancuran, tergantung pada tepat tidaknya individu-individu atau kelompok-kelompok masyarakat, terutama negara, berhasil dalam menyelaraskan kehidupan dan kegiatan mereka dengan jagad raya. Keselarasan antara kerajaan dan jagad raya dapat dicapai dengan menyusun kerajaan 
itu sebagai gambaran jagad raya atau, sebagai satuan jagad raya dalam bentuk kecil.

Menurut ajaran Buddhis pusat dari jagad raya adalah Gunung Meru. Gunung itu dikelilingi oleh tujuh buah samudra yang melingkar, dan di situ terdapat empat buah benua yang terletak di empat penjuru angin. Benua yang diselatan disebut Jambudwipa, tempat tinggal umat manusia. Keseluruhannya itu dilingkari oleh rangkaian pegunungan yang tinggi yang disebut Cakrawala. Di puncak Gunung Meru terdapat surga 33 dewa dengan kota Sudarsana, di mana Indra bersemayam sebagai raja dewa. Di lereng Meru terdapat surga yang terendah, tempat tinggal Catur Lokapala (empat dewa penjaga arah mata angin). Di bagian atas surga yang tertinggi masih terdapat lagi beberapa lapis surga (Geldern 1980: 1-5).

Pengertian kosmos dari percandian Muara Jambi digambarkan dalam bentuk arsitektur candi yang merupakan replika dari jagad raya. Candi-candi di Muara Jambi pada umumnya mempunyai pagar keliling dan diluar pagar terdapat parit yang mengelilinginya. Halaman di mana candi berdiri letaknya lebih tinggi dari permukaan tanah di sekitarnya. Hal ini menggambarkan bahwa bàngunan candi diumpamakan sebagai Gunung Meru, pagar ketiling diumpamakan sebagai rangkaian peguriungan yang mengelilingi pusat jagad raya, dan parit keliling diumpamakan sebagai samudra.

Penggambaran kelompok percandian seperti itu mempunyai dua maksud, yaitu:

1. sebagai pusat pemujaan, bentuk arsitektur setidaknya harus merupakan penggambaran dari jagad raya dalam bentuk kecil, dan

2. sebagai suatu tempat yang dianggap suci, tempat tersebut harus terhindar dari hal-hal yang kotor. Seperti kita ketahui bahwa Sungai Batanghari pada setiap musim hujan airnya meluap menggenangi daerah-daerah di sekitarnya. Oleh sebab itu, halaman percandi- 
an harus ditinggikan, dan dibuat parit-parit guna mempercepat kembalinya air limbah ke Sungai Batanghari.

Di suatu candi biasanya dipersembahkan saji-sajian dan dilakukan upacara-upacara keagamaan setiap hari, setiap bulan, dua kali sebulan, dua kali setahun, dan setahun sekali. Dari gambaran itu tentunya ada pemukiman di setiap candi, baik pemukiman penduduk biasa yang bertempat tinggal didalam lingkungan daerah perdikan dan mereka yang berkewajiban mengelolanya, maupun kediaman para pendeta yang mengurus dan memimpin upacara-upacara keagamaan, dan tempat tinggal budakbudak yang mungkin berkewajiban merawat bangunan candi dan apa yang ada di sekitarnya. Selain itu tentu ada tempat-tempat untuk melakukan upacara keagamaan dengan segenap persiapannya (Boechari 1977 : 106).

Penelitian Arkeologi yang dilakukan pada tahun 1981 - 1986 menghasilkan sisa-sisa pemukiman di baratdaya/selatan Candi Astano, timur dan barat Candi Tinggi, selatan Candi Gumpung, selatan Candi Kembarbatu, dan utara Candi Teluk. Di sebelahutara Candi Teluk, dekat tepi Sungai Batanghari, ditemukan sisa bangunan bata yang tidak permanen dengan denah seperti huruf $L$ yang kakinya ke arah selatan. Pada dua sisi lantai bangunan ini terdapat lubang yang diperkirakan bekas kayu. Diperkirakan bahwa sisa bangunan itu merupakan tempat tinggal pengelola bangunan Candi Teluk.

Menurut konsep agama Buddha, pemukiman seharusnya terletak di selatan Gunung Meru, yang dalam penggambarannya terletak di selatan bangunan candi atau istana. Dalam kenyataannya sisa pemukiman di muara Jambi tidak seluruhnya ditemukan di selatan candi. Di situs Muara Jambi yang terletak di sisi utara Sungai Batanghari, temuan sisa pemukiman sebagian besar berada di selatan candi; sedangkan yang terletak di sisi selatan Sungai Batanghari, temuan sisa pemukiman berada di utara candi. Hal ini dapat terjadi karena pemukiman 
biasanya mendekati ke arah sungai. Dengan demikian konsep agama Budha mengenai gambaran jagad raya diterapkan dengan tidak ketat, tergantung pada kondisi lingkungan alam sekitarnya.

Seperti kitaketahui, bahwa daerah aluvial sepanjang tepi sungai umumnya merupakan daerah yang berawarawa. Antara daerah rawa-rawa dan tepi sungai merupakan daerah tanggul alam (natural levee). Dengan pengalaman ada akalnya, manusia melihat gejala alam bahwa di suatu tempat, di antara daerah yang selalu tergenang air pada waktu air sungai meluap. Tempat ini (tanggul alam) dianggap layak untuk pemukiman dan segala macam aktivitas yang lain. Itulah sebabnya mengapa pola persebaran pusat upacara dan pemukiman disitus Muara Jambi dan situs lainnya yang ada di daerah tepi sungai atau mengikuti pola pemukiman hulu-hilir selaras dengan keadaan lingkungan (Mundardjito 1985 : 246).

\section{Kepurbakalaan Suakkandis}

Kepurbakalaan yang ditemukan di daerah Suakkandis terletak ke arah hilir dari situs Muara Jambi. Di daerah itu terdapat tiga situs yang lokasinya berseberangan, yaitu situs Ujung Plancu, situs Muara Kumpeh dan situs Sematang Pundung. Dikatakan berseberangan karena terletak di daerah pertemuan Sunqai Kumpeh dan Sungai Batanghari. Situs Ujung Plancu terletak di sebelah timur Sungai Kumpeh; Situs Muara Kumpeh di sebelah barat Sungal Kumpeh; dan Situs Sematang Pundung di sebelah utara Sungai Batanghari, di muka muara Sungai Kumpeh.

Situs Muara Kumpeh sudah lama dikenal, yaitu sejak abad ke-18. Menurut catatan Belanda, pada tahun 1707 Muara Kumpeh terpilih sebagai benteng pertahanan Vereenigde Dost-Indische Compagnie (VOC). Benteng tersebut pada tahun 1724 ditinggalkan, karena adanya pemberontakan melawan Belanda. Kemudian pada tahun 1834 di Muara Kumpeh ditempatkan pos militer, dan pada tahun 1847 dibuka pos untuk perdağangan umum (ENI 1917: 608-614, 762). 
Menurut catatan dari Kapten L.C. Crooke, seorang perwira Inggris, di Mual a Kumpeh (Muara Kampau) terdapat 13 rumah di sebelah kanan tempat pertemuan sungai, di anak Sungai Batanghari (Sungai Kumpeh). Permukaan tanahnya 10 kaki di atas permukaan air sungai pada waktu surut, akan tetapi tergenang air pada musim hujan (Anderson 1971 : 398). Kepurbakalaan yang terdapat di daerah pertemuan sungai ini antara lain berupa tonggak-tonggak kayu sisa bangunan (rumah tinggal), sisa perahu, pecahan keramik dan tembikar serta sampah dapur yang berupa tulang hewan yang teroksidasi.

Situs yang menarik di daerah pertemuan sungai ini adalah Situs Ujung Plancu. Di situs ini ditemukan tonggak-tonggak kayu sejumlah 16 buah, sisa perahu, pecahan keramik dan tembikar. Sisa perahu ditemukan pada kedalaman 16 meter dari permukaan tanah pada tebing Sungai Kumpeh. Dekat dengan temuan sisa perahu itu terdapat tonggak-tonggak kayu dimana di dekatnya terdapat akumulasi sampah dapur. Papan-papan kayu yang merupakan bagian dari lunas perahu berukuran tebal sekitar $3-5 \mathrm{~cm}$ dengan lebar sekitar $35 \mathrm{~cm}$. Bilah-bilah papan kayu ini satu sama lain diikat pada dua sisi yang memanjang, dengan dua batang pasak kayu pada salah satu papan.

Pecahan keramik yang ditemukan pada tebing sungai berupa pecahan tempayan Thailand dari abad ke-13 $\mathrm{M}$, keramik Cina Lung Quan dari abad ke $12-13 \mathrm{M}$ dan keramik Cina dari masa Dinasti Song (abad ke $11-12$ M).

Temuan arkeologis yang terdapat di daerah pertemuan sungai itu membuktikan kepada kita bahwa pemukiman pada masa lampau tidak jauh berbeda dengan pemukiman sekarang, seperti yang telah digambarkan oleh Kapten L.C. Crooke. Pemukiman pada waktu itu berupa rumah-rumah tinggal dari bahan kayu yang didirikan di atas tiang-tiang kayu di tepian sungai. Di bagian bawah 
biasanya dipakai sebagai tempat untuk menambatkan perahu. Apabila orang di sebuah rumah hendak membuang sampah dapurnya, cukup dengan membuangnya ke sungai yang ada di kolong rumah. Oleh sebab itu banyak sampah dapur yang terakumulasi dekat dengan tonggak-tonggak kayu. Kebiasaan seperti ini masih sering kita jumpai pada rumah penduduk yang tinggal di tepian sungai.

Dalam kitab Chau-ju-kua yang ditulis oleh Chu-fanchi tahun $1225 \mathrm{M}$ disebutkan bahwa penduduk. San-fo-tsi terpencar di luar kota atau tinggal di atas rakit-rakit yang beratap ilalang yang ditambatkan pada tepian sungai (Hirth dan Rockhill 1967:62). Di dalam berita Cina ini tidak disebutkan mengenai rumah yang bertiang yang didirikan di tepian sungai. Rumah yang penggambarannya seperti pada berita Cina itu pada mase kini masih banyak ditemukan di tepi-tepi sungai besar di Sumatera. Jadi tidak mustahil kalau pada waktu Chu-fanchi mengunjungi San-fo-tsi tentu dilihat juga rumah bertiang kayu yang didirikan di tepian sungai, tetapi tidak (sempat) dicatat.

\section{Kepurbakalaan Koto Kandis}

Situs Koto Kandis letaknya sekitar 100 kilometer ke arah muara dari situs Muara Jambi, di tepi sebeiah timur sungai Niur yang merupakan cabang surigai Batanghari. Situs ini ditemukan pada tahun 1981 ketika seorang anak bermain di tepian sungai dan menemukan sebuah arca perunggu. Berdasarkan langgarnnya, langgam cola, arca ini berasal dari sekitar abad ke-13 -- $14 \mathrm{M}$. (McKinnon 1984:62-64). Dari ciri dan atribut yang ada pada arca itu, dengan mengacu pada Liebert (1976:81), bahwa arca perunggu tersebut adalah arca Dipalaksmi.

Temuan lain yang terdapat di situs Koto Kandis adalah sebuah batu pipisan yang pada salah satu sisinya terdapat tulisan yang berbunyi //cu a sa $\mathrm{r} / /$. Berdasarkan bentuk hurufnya, huruf Jawa Kuno, diperkirakan artefak ini berasal dari sekitar abad ke-7 dan $8 \mathrm{M}$. Di se- 
kitar tempat temuan arca Dipalaksmi dan batu pipisan banyak ditemukan keramik baik yang pecahan maupun utuhan. Keramik-keramik yang ditemukan dari situs itu berasal dari masa Dinasti Song (sekitar abad ke-12 $13 \mathrm{M})$. Bentuknya beraneka ragam, seperti bentuk cepuk, piring, mangkuk, kendi dan tempayan. Selain itu juga ditemukan botol mercury.

Adanya temuan arkeologis tersebut menunjukkan kepada kita bahwa daerah tersebut sudah dimukimi sekurangnya sejak abad ke-10 M. Keramik yang ditemukan di tepi-tepi sungai dan di daratan tanggul alam sepanjang lebih dari 100 meter dan lebar lebih dari 50 meter, menunjukkan padatnya pemukiman. Luas area yang dimukimi di daerah tersebut pada waktu itu mungkin tidak jauh berbeda dengan luas pemukiman masa kini. Meskipun kita sudah dapat mengetahui luas area situs, penelitian arkeologi yang intensif dan sistematis di situs ini belum pernah dilakukan.

\section{Penutup}

Daerah aliran sungai Batanghari yang cukup luas itu telah memiliki sejarah yang cukup panjang. Beberapa situs arkeologi yang ditemukan di daerah itu menunjukkan adanya pemusatan pemukiman kuno di beberapa tempat, di tepi sungai. Pada masa itu sungai merupakan sarana transportasi yang penting dari dan ke daerah pedalaman. Namun hingga kini belum dilakukan penelitian mengenai masalah angkutan dalam kaitannya dengan pola pemukiman.

Pengangkutan barang dan manusia melalui jalan darat di wilayah Asia Tenggara baru dikembangkan pada abad ke-19. Menurut Drennan, penelitian mengenai pengangkutan tradisional di daerah Amerika Tengah berhasil membuktikan bahwa angkutan melalui air jauh lebih efisien dibandingkan dengan angkutan melalui darat (1984). Dilihat dari lingkungan alamnya, yang mempunyai banyak sungai, transportasi dari dan ke arah pedalaman 
daerah Jambi dilakukan melalui sungai. Biasanya di jalur transportasi itu terdapat kelompok-kelompok pemukiman. Besar kecilnya kelompok pemukiman dapat tergantung pada faktor strategis tidaknya tempat tersebut.

Ada pendapat yang mengatakan bahwa antara kerajaan di daerah pedalaman dan kerajaan di daerah pesisir di Indonesia terdapat perbedaan yang menyolok ( $T$ jandrasasmita $1975: 149)$. Pendapat ini didasarkan atas pandangan dari Fox mengenai sejarah geografi di Eropa. Di Eropa dan di Infonesia pada masa yang sama, kota dagang di daerah perbatasan di antara kerajaan-kerajaan agraris lebih cepat berkembang dibandingkan dengan pusatnya yang ada di pedalaman (Fox 1971). Komoditi yang dihasilkan daerah pedalaman dipasarkan di daerah pesisir lebih banyak didatangi oleh pedagang-pedagang dari negara lain.

Berdasarkan tempat ditemukannya Prasasti Karangberahi di daerah Jambi Hulu, berita Cina yang ditulis oleh I-tsing, dan tempat ditemukannya arca Amoghapasa, dapat diduga bahwa pusat Kerajaan Malayu ada di daerah pedalaman. Menurut Kitab Pararaton, dalam rangka ekspedisi Pamalayu, pada tahun 1275 Kertanagara mengirim arca Amoghapasa ke Malayu. Arca ini ditemukan di Rambahan, daerah perbatasan antara Propinsi Jambi dan Sumatera Barat. Kalau pusat Kerajaan Malayu ada di daerah pedalaman, tentu di daerah itu ditemukan sebuah situs yang cukup besar dan luas yang mencerminkan sebuah pusat kerajaan.

Namun dibandingkan dengan Situs Muara Jambi, Situs Rambahan jauh lebih kecil. Ini dapat memberikan gambaran kepada kita bahwa daerah pesisir jauh lebih cepat berkembang jika dibandingkan dengan daerah pedalaman. Temuan keramik yang berasal dari berbagai tempat dan jaman menunjukkan bukti bahwa daerah pesisir lebih banyak menjalin hubungan dengan luar. 
Daerah pedalaman Jambi yang diduga merupakan pusat Kerajaan Malayu, merupakan daerah yang lebih tua dibandingkan dengan daerah pesisir. Di daerah pedalaman itu ditemukan prasasti Karangberahi yang berasal dari sekitar abad ke-7 M. Prasasti ini merupakan prasasti persumpahan yang isinya kutukan bagi siapa yang memberontak terhadap kekuasaan Sriwijaya.

Adanya penyebutan Mo-lo-yeu dalam berita I-tsing, prasasti Karangberahi, arca Amoghapasa, dan penyebutan Malayu dalam kitab Pararaton dan Nagarakertagama membuktikan kepada kita bahwa Kerajaan Malayu sudah ada sejak abad ke $7 \mathrm{M}$. Rupa-rupanya kerajaan ini masih tetap hidup sampai masa Majapahit (abad ke-14). Hanya saja, kerajaan ini selalu dikuasai oleh negara lain, seperti Sriwijaya, Singhasari, dan Majapahit. Dengan, lamanya kelangsungan hidup kerajaan ini, dan lokasinya yang tidak berubah (sekitar wilayah Propinsi Jambi), tentunya di daerah sepanjang aliran sungai Batanghari masih banyak terdapat pemusatan pemukiman kuno. Berdasarkan fakta-fakta di lapangan, ditafsirkan bahwa pola pemukiman di daerah aliran sungai Batanghari adalah memanjang sepanjang tepian sungai, dan bertempat pada tanggul alam.

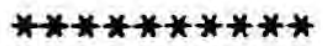




\section{KEPUSTAKAAN}

Anderson, J. 1971. Mission to the East Coast of Sumatra in 1823. Kuala Lumpur : Oxford in Asia Historical Reprint.

Boechari. 1977. Candi dan Lingkungannya, MISI, VII [2]. Jakarta Bhratara. HIm. 89 - 114.

Drennan, R.D. 1984. Long distance Transport Costs in Pre-Hispanic America. American Anthropologist, 86 [1]. HIm. 105 - 12.

Fox. 1971. History in Geographic Perspective. New York: Norton.

Hadiwisastra, Sapri. 1983. Laporan Penelitian Geologi di Daerah Muara Jambi. Tidak diterbitkan.

Heine-Geldern, Robert von. 1980. Konsepsi Kerajaan di Asia Tenggara. Jakarta : Bhratara.

Hirth, F. dan W.W. Rockhill. 1911. Chu-Ju-Kua, His Work on Chinese and Arab Trade in Twelfth and Thirteenth Century, Entitled Chufan-Chi. St. Pietersburg. [Reprint, New York : Paragon, 1966; Taipei : 1967].

Kartodirdjo, Sartono. 1977. Masyarakat Kota dan Kelompok-kelompok Sosial. Jakarta: Bhratara Karya Aksara.

Liebert, Gosta. 1976. Iconographic Dictionary of the Indian Religions. Hinduism-Buddhism-Jainism. Leiden : E.J. Brill.

Lith, P.A. van der (peny.]. 1976. Encyclopeadie van Nerderlandsch-Indie, Vol. II. Leiden: E.J. Brill.

McKinnon, E. Edwards. 1982. New Data for Studying the Early Coastal Line in the Jambi Area, JMBRAS, LVII [1]. HIm. 56-66. 
Mundardjito. 1985. Pola Pusat Upacara di Situs Muara Jambi, Rapat Evaluasi Hasil Penelitian Arkeologi II. Jakarta : Pusat Penelitian Arkeologi Nasional. Hlm. 241 52 .

Obdeyn, V. De. 1942. Oudezeehandelsweg door de Straat van Malaka in verband met de geomorfologie

der Selat-Eilanden, T.A.G., LIX. Hlm. 742-78.

Sartono, S. 1919. Pusat-pusat Kerajaan Sriwijaya Berdasarkan Interpretasi Paleogeografi, Pra Seminar Penelitian Sriwijaya. Jakarta : Pusat Penelitian Purbakala dan Peninggalan Nasional. Hlm. 43- 73.

Soekmono, R. Garis Pantai Sriwijaya. Amerta, 3. Jakarta: Pusat Penelitian Arkeologi Nasional. Hlm. 30 - 33.

Sumadio, Bambang [peny.]. 1974. Jaman Kuna. Sejarah Nasional Indonesia, II. Jakarta: Departemen Pendidikan dan Kebudayaan.

Tjandrasasmita, Uka [peny.] • 1974. Jaman Pertumbuhan dan Perkembangan Kerajaan-kerajaan Islam di

Indonesia, Sejarah Nasional Indonesia, III. Jakarta : Departemen Pendidikan dan Kebudayaan.

Wolters, 0. W. 1974. Early Indonesia Commerce: A Study of the Origins of Sriwijaya. Ithaca: Cornell University Press. 